\title{
Insecticidal effect of garlic essential oil on Diatraea saccharalis (Fabricius, 1794) (Lepidoptera: Crambidae) eggs
}

Studies have reported the resurgence of insect pests that are resistant to chemical and, more recently, to biological pesticides. Diatraea saccharalis is one of the main pests in sugarcane crops and responsible for large losses in the sugar and alcohol industries. The use of plant extracts including garlic essential oil (Allium sativum) which contains allicin, a compound that interferes with biochemical and physiological factors of target insects is considered an efficient and sustainable alternative for integrated pest management. The objective of this study was to test the toxicity of garlic essential oil on D. saccharalis eggs by analyzing rates of unhatched eggs, changes in external morphology, and esterases profile, enzymes related to insect resistance. For this, 24, 48, and 72-h-old eggs were immersed in $0.1,0.5$, and $1 \%$ garlic essential oil solutions for 2 min. Observations on embryonic development were made every 24-h for 72-h. Data on unhatched eggs were collected 288 -h after treatments. For the esterases profile, eggs at $24-\mathrm{h}$ after treatment with $1 \%$ solution were used. Eggs at 24 -h-old, showed the least resistance to bioinsecticide, being that, $24-\mathrm{h}$ after treatments with solutions $0.1,0.5$, and $1 \%$, unhatched rates $80,91.7$, and $89.2 \%$, respectively. The absence of embryos, ruptures, and protrusions on the chorionic region, and partial inhibition of EST-9, 10, and 11 were observed 24-h after the bioassays. These results demonstrate that garlic essential oil affects D. saccharalis eggs, partially inhibiting enzymes related to the insect immune system and can be used as a sustainable alternative for the integrated management of this insect pest.

Keywords: Sugarcane borer; Alternative control; Esterase; Melanization; Integrated pest management.

\section{Efeito insecticida do óleo essencial de alho em ovos da Diatraea saccharalis (Fabricius, 1794) (Lepidoptera: Crambidae)}

\begin{abstract}
Estudos têm relatado o ressurgimento de insetos pragas resistentes a inseticidas químicos, e recentemente biológicos. Diatraea saccharalis é uma das principais pragas na cultura canavieira, sendo responsável por grandes perdas nas indústrias sucroalcooleiras. $\mathrm{O}$ uso de extratos vegetais, incluindo o óleo essencial de alho (Allium sativum), contém como ativo a alicina, um composto que interfere nos fatores bioquímicos e fisiológicos dos insetos, sendo considerado uma alternativa eficiente e sustentável para o manejo integrado de pragas. O objetivo deste estudo foi testar a toxicidade do óleo essencial de alho em ovos da D. saccharalis, analisando os percentuais de ovos não eclodidos, alterações na morfologia externa e perfil de esterases, enzimas relacionadas à resistência em insetos-alvo. Para isso, ovos com 24, 48 e 72-h de idades foram imersos em soluções de óleo essencial de alho à $0,1,0,5$ e $1 \%$ por 2 min. Observações sobre o desenvolvimento embrionário foram feitas a cada 24-h por 72-h. Dados de ovos não eclodidos foram coletados 288-h após os bioensaios. Para o perfil de esterase, foram utilizados ovos tratados com solução 1\%, 24-h após os bioensaios. Ovos com 24-h de idade, demonstraram menor resistência ao bioinsetida, sendo que, 24-h após tratamentos com soluções de $0,1,0,5$ e $1 \%$, foram obtidas as taxas de não eclosão $80,91,7$ e $89,2 \%$, respectivamente. A ausência de embriões, rupturas e protrusões na região coriônica e inibição parcial de EST-9, 10 e 11 foram observadas nos ovos, 24-h após os bioensaios. Estes resultados demonstram que o óleo essencial de alho afeta os ovos de D. saccharalis, inibindo parcialmente as enzimas relacionadas ao sistema imunológico de insetos e pode ser usado como uma alternativa sustentável para o manejo integrado desta praga.
\end{abstract}

Palavras-chave: Broca da cana-de-açúcar; Controle alternativo; Esterase; Melanização; Manejo integrado de pragas.

Topic: Desenvolvimento, Sustentabilidade e Meio Ambiente

Reviewed anonymously in the process of blind peer
Received: 02/07/2021

Approved: 28/07/2021
Daniele Araujo Canazart (iD)

Universidade Estadual de Maringá, Brasil http://lattes.cnpq.br/6729704204547247 http://orcid.org/0000-0003-3981-3423

danycanazart@gmail.com

\section{Bruno Vinicius Daquila (iD)}

Universidade Estadual de Maringá, Brasil http://lattes.cnpq.br/7317834230980773 https://orcid.org/0000-0003-3540-3187 bv.ds@hotmail.com

Larissa Carla Lauer Schneider (iD) Universidade Estadual de Maringá, Brasil http://lattes.cnpq.br/3066037738016819 http://orcid.org/0000-0002-7540-5294 lari uem@yahoo.com.br

\author{
Camila Vieira da Silva \\ Faculdade de Apucarana, Brasil \\ http://lattes.cnpq.br/1123838490838295 \\ milabio@yahoo.com.br
}

Adriana Aparecida Sinópolis Gigliolli id Universidade Estadual de Maringá, Brasil http://lattes.cnpq.br/4911390091489064 http://orcid.org/0000-0002-2752-642X adrianasinopolis@hotmail.com

Maria Claudia Colla Ruvolo-Takasusuki (ic Universidade Estadual de Maringá, Brasil http://lattes.cnpq.br/2318400558555562 http://orcid.org/0000-0002-2028-9281 claudia.ruvolo@gmail.com
Helio Conte (iD)

Universidade Estadual de Maringá, Brasil http://lattes.cnpq.br/7805899028515988 http://orcid.org/0000-0002-2090-0554 hconte@uem.br
Referencing this:

CANAZART, D. A.; DAQUILA, B. V.; SCHNEIDER, L. C. L.; SILVA, C. V.; GIGLIOLLI, A. A. S.; RUVOLO-TAKASUSUKI, M. C. C.; CONTE, H.. Insecticidal effect of garlic essential oil on Diatraea saccharalis (Fabricius, 1794) (Lepidoptera: Crambidae) eggs. Revista Ibero Americana de Ciências Ambientais, v.12, n.7, p.434-447, 2021. DOI: http://doi.org/10.6008/CBPC2179-6858.2021.007.0038 


\section{INTRODUCTION}

Bioinsecticides based on microorganisms are utilized as an alternative to chemical pesticides, and their use can protect plants from attacks by insect pests (COSTA et al., 2012). Although bioinsecticides are considered safe, the sustainability of their use has raised several questions, for instance, on the interaction of toxins with non-target organisms and the evolution of resistance in target insects (FONTES et al., 2002; CARVALHO et al., 2018; LIAO et al., 2019).

Resistance to chemical (TERRIERE, 1984) or biological insecticides (BALLESTER et al., 1999; XU et al., 2016; KIM et al., 2017; YANG et al., 2018; RIAZ et al., 2020) may be associated with responses of the immune system (JACOBS et al., 2014) such as the activation of proteases (DUBOVSKIY et al., 2008; NAKHLEH et al., 2016) and esterases (RUVOLO-TAKASUSUKI et al., 2002), which are enzymes responsible for containing pathogens and substances harmful to the organism (LAUFER, 1961). In lepidopterans, esterases (SHARE et al., 1988) and proteases (RAIKHEL et al., 1992) are synthesized and stored in the eggs during vitellogenesis and were described by Maki et al. (2001), Ruvolo-Takasusuki et al. (2002), and Kanost et al. (2012).

Diatraea saccharalis is a holometabolous lepidopteran considered is one of the main pests in sugarcane crops, causing great damage to the sugar and alcohol industry (BERGAMO et al., 2019; DAQUILA et al., 2019a; DAQUILA et al., 2019b; DAQUILA et al., 2021). The control of this species populations using plant extracts has been suggested in many studies as a promising and sustainable method (e.g., SILVA et al., 2012; SILVA et al., 2013; BELL et al., 2015; SCHNEIDER et al., 2017; LOURENÇO et al., 2018; SCUDELER et al., 2019; VILLEGAS-AGUDELO et al., 2019; MAGIEROWICZ et al., 2020).

Garlic (Allium sativum) essential oil has a strong and characteristic smell (ATTIA et al., 2011; SANTOS et al., 2012). The main components in its extract are thioacrolein, ajoene, and allicin (2-Propene-1sulfinothioic acid S-2-propenyl ester), compounds that interfere in biochemical and physiological factors of target insects (TSAI et al., 2012; IBRAHIM, 2020). Allicin, in particular, acts on enzymatic degradation (DOUGOUD et al., 2019), and its use is considered a complementary alternative for integrated pest management (ISMAN et al., 2006; ISMAN et al., 2014; OSMAR et al., 2020).

Considering that essential oils have short residual activity and are less persistent in the environment than conventional pesticides (MIRESMAILLI et al., 2006; CLOYD et al., 2009), the interference of allicin on enzyme activity (DOUGOUD et al., 2019) may reduce the selection of resistant insects. The application of this substance on insect eggs is suggested to lead to embryonic mortality, but this has not yet been thoroughly studied (SHU-SHENG et al., 1997). The present study aimed to evaluate the biocontrol effect of garlic essential oil on $D$. saccharalis eggs at different ages by investigating external morphology alterations, embryo development, and possible responses of the immune system using an esterase profile analysis.

\section{MATERIALS AND METHODS}

\section{D. saccharalis eggs}

Glass slides containing 24,48 , and 72 -h-old $D$. saccharalis eggs were obtained from the Laboratory 
for Biological Control, Morphology, and Cytogenetics of Insects, Department of Biotechnology, Genetics and Cell Biology, State University of Maringá-UEM, Maringá, Paraná, Brazil ( $\left.23^{\circ} 25^{\prime} 30^{\prime \prime} \mathrm{S}, 51^{\circ} 56^{\prime} 20^{\prime \prime} \mathrm{W}\right)$.

\section{Bioassays}

Bioassays were carried out using garlic (A. sativum) essential oil containing $45 \%$ allicin (2-Propene-1sulfinothioic acid S-2-propenyl ester) - C6H10OS2 (CAS certified organic product: 8000-78-0, commercially obtained from Destilaria Bauru, São Paulo, Brazil). Three concentrations: 0.1\% (0.045 mg a.i./mL), 0.5\% (0.225 $\mathrm{mg}$ a.i. $/ \mathrm{mL})$, and $1 \%(0.45 \mathrm{mg}$ a.i. $/ \mathrm{mL})$, were obtained by diluting the commercial product in autoclaved distilled water at $\mathrm{pH} 7.0$ and $25{ }^{\circ} \mathrm{C}$. The solutions were mixed using a vortex (Global Trade Technology ${ }^{\circledR}$, Monte Alto, São Paulo, Brazil) for 2 min immediately before the bioassays. The eggs ( $n=40)$ were submerged in $30 \mathrm{~mL}$ aliquots of biopesticide solutions for $2 \mathrm{~min}$. For the control group, an autoclaved distilled water at $\mathrm{pH} 7.0$ and $25^{\circ} \mathrm{C}$ was used. Each bioassay was performed in triplicate.

The slides were kept in $90 \times 15$ mm glass Petri dishes containing moist filter paper and kept in a conditioned room at $25 \pm 2{ }^{\circ} \mathrm{C}$, 12-h photoperiod, and $70 \pm 10 \%$ Relative Humidity (RH) following Araújo (1987). Observations on morphological changes and embryonic development were performed every 24 for 72-h. Embryo mortality was evaluated after 288-h.

\section{Light microscope analyses}

Control and treated eggs were collected 24 and 72-h after the beginning of the bioassays $(n=4$ per group), analyzed as described by Chen (1984) under a light microscope (Omicron medical microscope Axioskop 40; Carl Zeiss, Gottingen, Germany) and acquired using AxioCam MRc (Carl Zeiss, Oberkochen, Germany).

\section{Scanning electron microscope (SEM) analyses}

Control and treated eggs were collected 24,48 , and 72 -h after the beginning of the bioassays and put in $1 \%$ garlic essential oil ( $n=15$ per group). These eggs were then fixed in alcoholic Bouin solution (7.5 $\mathrm{mL}$ formaldehyde, $2 \mathrm{~mL}$ picric acid, and $0.5 \mathrm{~mL}$ acetic acid; $\mathrm{v} / \mathrm{v})$ for $24-\mathrm{h}$ at room temperature $\left(25^{\circ} \mathrm{C}\right)$. These samples were dehydrated in increasing concentrations of ethanol $(70,80,90$, and $100 \%$; $v / v)$ and then subjected to critical point drying (Leica EM CPD030, Leica Biosystems, Wetzlar, Germany), coated with a gold layer in an IC-50 metallizer (Shimadzu, Kyoto, Japan), and analyzed using a Quanta 250 scanning electron microscope FEI (FEI Company, Eindhoven, Netherlands) at the Microscopy Center of the Complex of Research Support Center of the State University of Maringá, Paraná, Brazil.

\section{Analyses of esterase profile using polyacrylamide gel electrophoresis (PAGE)}

Esterases were analyzed using standard methods: DAVIS (1964) and LAEMMLI (1970). Control and treated (1\% solution) eggs were analyzed in vertical PAGE $(12 \%)$, with the stacking gel at $4 \%$. The 24,48 , and 72-h-old eggs $(n=10)$ were macerated in $25 \mu$ l of $0.1 p$-mercaptoethanol $1 \%$ containing $10 \%$ glycerol. Then, 
$20 \mu \mathrm{l}$ of each sample was applied to the gel in six repetitions, and these gels were electrophoresed for 4-h at $4{ }^{\circ} \mathrm{C}$ and a constant voltage of $200 \mathrm{~V}$. Tris-glycine buffer (0.1 M, pH 8.3) was added to fill the upper and lower compartments of the electrophoresis chamber. For esterase identification, the gels were preincubated in 50 $\mathrm{mL}$ of phosphate buffer $(0.1 \mathrm{M}, \mathrm{pH} \mathrm{6.2)}$ for $30 \mathrm{~min}$, followed by the removal of the buffer and addition of the staining solution. The gels were maintained in the dark at $25 \pm 1{ }^{\circ} \mathrm{C}$ until the complete visualization of the bands ( 1-h of incubation). The gels were then maintained in a preservative solution (acetic acid and water) and scanned.

\section{Statistical analyses}

The mortality data collected after 288-h were submitted to statistical analysis using the GraphPad Prism 5.0 software and are herein expressed as mean \pm standard error. Data were compared by analysis of variance (ANOVA) followed by Tukey's test at a level of significance $(p<0.05 \%)$.

\section{RESULTS}

\section{Unhatched eggs}

All tested concentrations of garlic essential oil were toxic to the $D$. saccharalis eggs, causing changes in embryo development that resulted in increased mortality and reduced eclosion rates. The reduction of the hatching rate in 24,48 , and 72 -h-old eggs treated with garlic essential oil showed significant differences $(p<$ 0.05). Multiple comparison analysis indicated that all treatment concentrations in eggs at different ages differed from the control $(p<0.001)$. The reduction in the hatching rate of treated $D$. saccharalis eggs was proportional to the increase in garlic essential oil concentration; however, the percentage of unhatched eggs reduced with the increase in the age of the treated eggs, thus indicating a relationship between egg age and concentration of garlic essential oil (Figures $1 \mathrm{~A}-\mathrm{C}$ ).
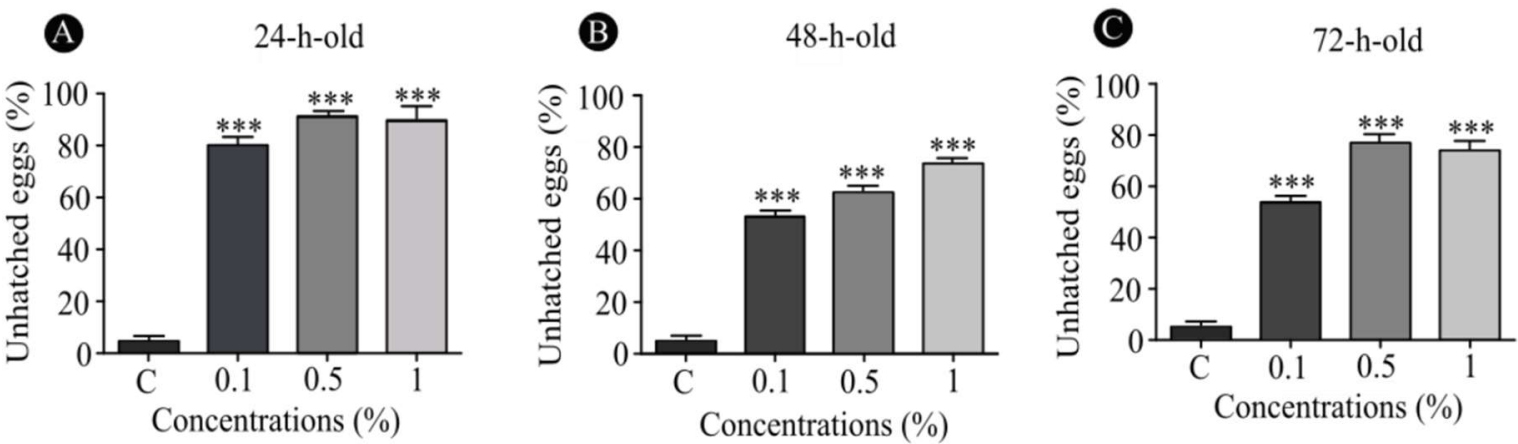

Figure 1: Percentages of unhatched $D$. saccharalis eggs at different ages and exposed to different treatments with garlic essential oil after 288-h. (A) 24-h-old eggs. (B) 48-h-old eggs. (C) 72-h-old eggs. Control (C). ${ }^{* * *} p<0.001$.

The multiple comparison analysis of the percentage of 24-h-old unhatched eggs showed significant differences between the control group $(5.0 \pm 1.4 \%)$ and each of the concentrations of oil- $0.1 \%(80.0 \pm 2.5 \%)$, $0.5 \%(91.7 \pm 1.7 \%)$, and $1 \%(89.2 \pm 4.6 \%)-$, but the values of the different treatments did not differ among themselves. For 48 -h-old eggs, the control group $(5.0 \pm 1.4 \%)$ differed from each of the treatments- $0.1 \%$ 
(54.2 $\pm 1.7 \%), 0.5 \%(62.5 \pm 4.3 \%)$, and $1 \%(72.5 \pm 1.4 \%)$-, but treatments $0.1 \%$ and $0.5 \%$ and $0.5 \%$ and $1 \%$ did not differ from each other. For 72-h-old eggs, the control groups $(5.0 \pm 1.4 \%)$ differed from the treatments$0.1 \%(53.3 \pm 2.2 \%), 0.5 \%(76.7 \pm 3.0 \%)$, and $1 \%(73.3 \pm 3.0 \%)$-, and $0.1 \%$ differed from 0.5 and $1 \%$, whereas no significant difference was observed between the latter two groups (Table 1).

Table 1: Percentages of unhatched 24, 48, and 72-h-old D. saccharalis eggs under different concentrations of garlic essential oil after 288-h. Control (C), Mortality (M) and eclosion (E).

\begin{tabular}{lllllll}
\hline Garlic & \multicolumn{2}{l}{ Age of the eggs } \\
\cline { 2 - 7 } $\begin{array}{l}\text { essential oil } \\
\text { dilution (\%) }\end{array}$ & \multicolumn{2}{c}{ 24-h-old } & \multicolumn{2}{c}{ 48-h-old } & \multicolumn{2}{c}{ 72-h-old } \\
C & $5.0 \pm 1.4^{\mathrm{a}}$ & $95.5 \pm 1.4^{\mathrm{a}}$ & $5.0 \pm 1.4^{\mathrm{a}}$ & $95.5 \pm 1.4^{\mathrm{a}}$ & $5.0 \pm 1.4^{\mathrm{a}}$ & $95.5 \pm 1.4^{\mathrm{a}}$ \\
0.1 & $80.0 \pm 2.5^{\mathrm{b}}$ & $20.0 \pm 2.5^{\mathrm{b}}$ & $54.2 \pm 1.7^{\mathrm{b}}$ & $45.8 \pm 1.7^{\mathrm{b}}$ & $53.3 \pm 2.2^{\mathrm{b}}$ & $46.7 \pm 2.2^{\mathrm{b}}$ \\
0.5 & $91.7 \pm 1.7^{\mathrm{b}}$ & $8.3 \pm 1.7^{\mathrm{b}}$ & $62.5 \pm 4.3^{\mathrm{bc}}$ & $37.5 \pm 4.3^{\mathrm{bc}}$ & $76.7 \pm 3.0^{\mathrm{c}}$ & $23.3 \pm 3.0^{\mathrm{c}}$ \\
1 & $89.2 \pm 4.6^{\mathrm{b}}$ & $10.8 \pm 4.6^{\mathrm{b}}$ & $72.5 \pm 1.4^{\mathrm{c}}$ & $27.5 \pm 1.4^{\mathrm{c}}$ & $73.3 \pm 3.0^{\mathrm{c}}$ & $26.7 \pm 3.0^{\mathrm{c}}$ \\
\hline
\end{tabular}

Means followed by the same letter in the same column are not statistically different according to Tukey's test $(p>0.05)$. Different letters indicate significant differences.

\section{Observational analysis}

The analysis of slides with $D$. saccharalis eggs evidenced the chorionic regions and the yolk. The embryo is inserted in the yolk region, which is delimited by a thin membrane (Figures $2 \mathrm{~A}-\mathrm{C}$ ). The control eggs and embryos were observed after 48-h-old (Figure 2A), 72-h-old (Figure 2B), and 96-h-old (Figure 2C). In the 72-h-old eggs, the stomodeum and advanced segmentation regions were observed (Figure 2B). The membrane persisted in all eggs that were last observed 72-h after bioassays. The embryos had an elongated body and their yolk region reduced with development (Figure $2 \mathrm{C}$ ).

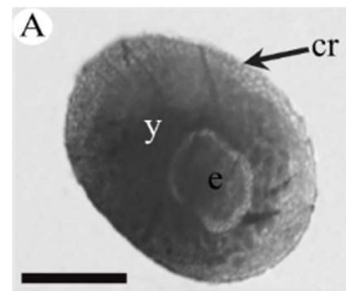

D
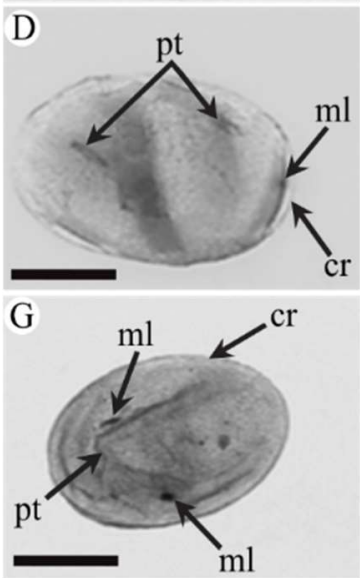
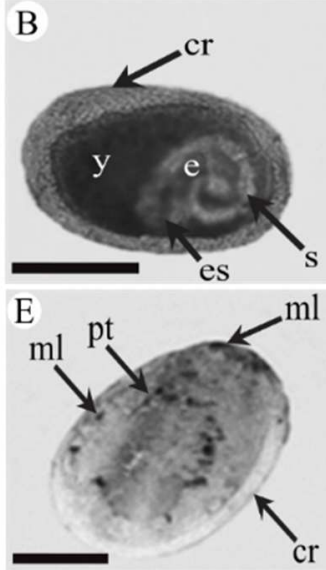

$\mathrm{H}$

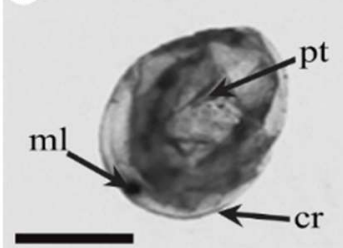

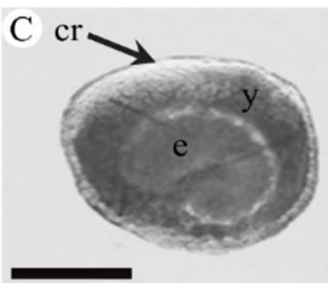

$\mathrm{F} \mathrm{ml}$

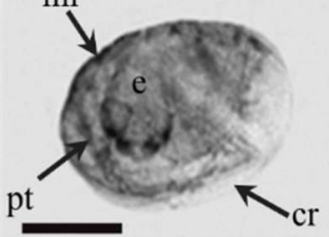

I

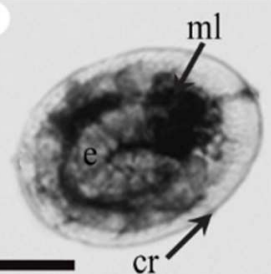

Figure 2: Embryonic development in D. saccharalis eggs 48 and 72-h after treatment with garlic essential oil. (A): 24-hold control group; (B): 48-h-old eggs; (C): 72-h-old eggs. The eggs are surrounded by the chorion (cr) and contain yolk (y) for embryonic (e) nutrition in the central region. At 48-h, the stomodeum (es) and segmentations (s) can be observed. (D and G): Eggs treated with a $1 \%$ solution for $24-\mathrm{h}$; $(\mathrm{E}$ and H) 48-h; and (F and I) 72-h. (D and G): After treatment, melanization (ml) and protrusions (pt) are observed in the chorionic region of eggs at all ages. In 24 and 48-h-old eggs, the embryo appears to degenerate; in 72-h-old eggs, the embryonic development suffers interference. Scale bar A-I = $200 \mu \mathrm{m}$. 
Eggs at all ages maintained the same characteristics 24 and 48-h after the bioassays; therefore, we analyzed only images of observations made 48 and 72-h after treatments. An absence of embryo development was observed in 24 and 48 -h-old eggs submitted to the $1 \%$ treatment. All treated eggs showed a reduction in volume, evidenced by the flattening of the chorion (Figures $2 \mathrm{D}-\mathrm{E}, \mathrm{G}-\mathrm{H}$ ). In treated eggs of all ages, melanization and chorionic protrusions were observed until the end of the observations (Figures 2DH). In 72-h-old eggs, the embryonic development was maintained, but the embryos presented degenerations (Figures $2 \mathrm{~F}$ and $\mathrm{I}$ ).

\section{Scanning electron microscope}

Ultrastructurally, D. saccharalis ovoposite superimposed eggs (Figures 3A-D). The 24-h-old control eggs observed 24,48 , and 72 -h after bioassays did not show changes in their external morphology. Eggs are joined by a cementing material, and they show a uniform chorion featuring chorion sculptures in predominantly pentagonal format (Figure 3A). After 24-h of treatment, the eggs remained together, but only superficially, and protrusions and bumps were observed (Figure 3B). At 48-h of treatment, the previously observed characteristics were maintained, but the eggs showed a reduction in volume, with folds at their ends (Figure 3C); these characteristics became more evident at 72-h of treatment (Figure 3D). Control and treated eggs had circular openings that were present on the chorion sculptures, the aeropiles. Chorion sculptures and aeropiles were not affected by the treatment and their shapes were maintained (Figures 3DF).

\section{Esterase profile}

PAGE analysis identified esterases EST-6, 8, 9, 10, and 11, attributed to the expression of five loci in D. saccharalis eggs (Figure 4A). Regarding the specificity to the substrates $\alpha$-naphthyl acetate and $\beta$-naphthyl acetate, EST- 6 was classified as an $\alpha$-esterase and EST- 8 as a $\beta$-esterase. The other esterases hydrolyzed both substrates. Based on the pattern of bands in the gels, only EST-9 had a dimeric structure, while the others had no quaternary structure.

The analysis of eggs after different oviposition periods demonstrated that there was a differential expression of these isoenzymes during embryonic development. While EST-6, 8, and 11 were expressed in 24, 48, and 72-h-old eggs, EST-10 was apparently expressed in 24 and 72-h old eggs, but not in 48-h old ones. Similarly, EST-9 was not expressed in all analyzed samples and was predominant in some 48 and 72 -h old egg samples (Figure 4A). Treatment of eggs with garlic oil extract partially inhibited EST-6, 9, 10, and 11 after 72 h (Figure 4B). In other periods, esterases in eggs treated with the bioinsecticide (Figure 4B) were not significantly different from those in the control eggs. 

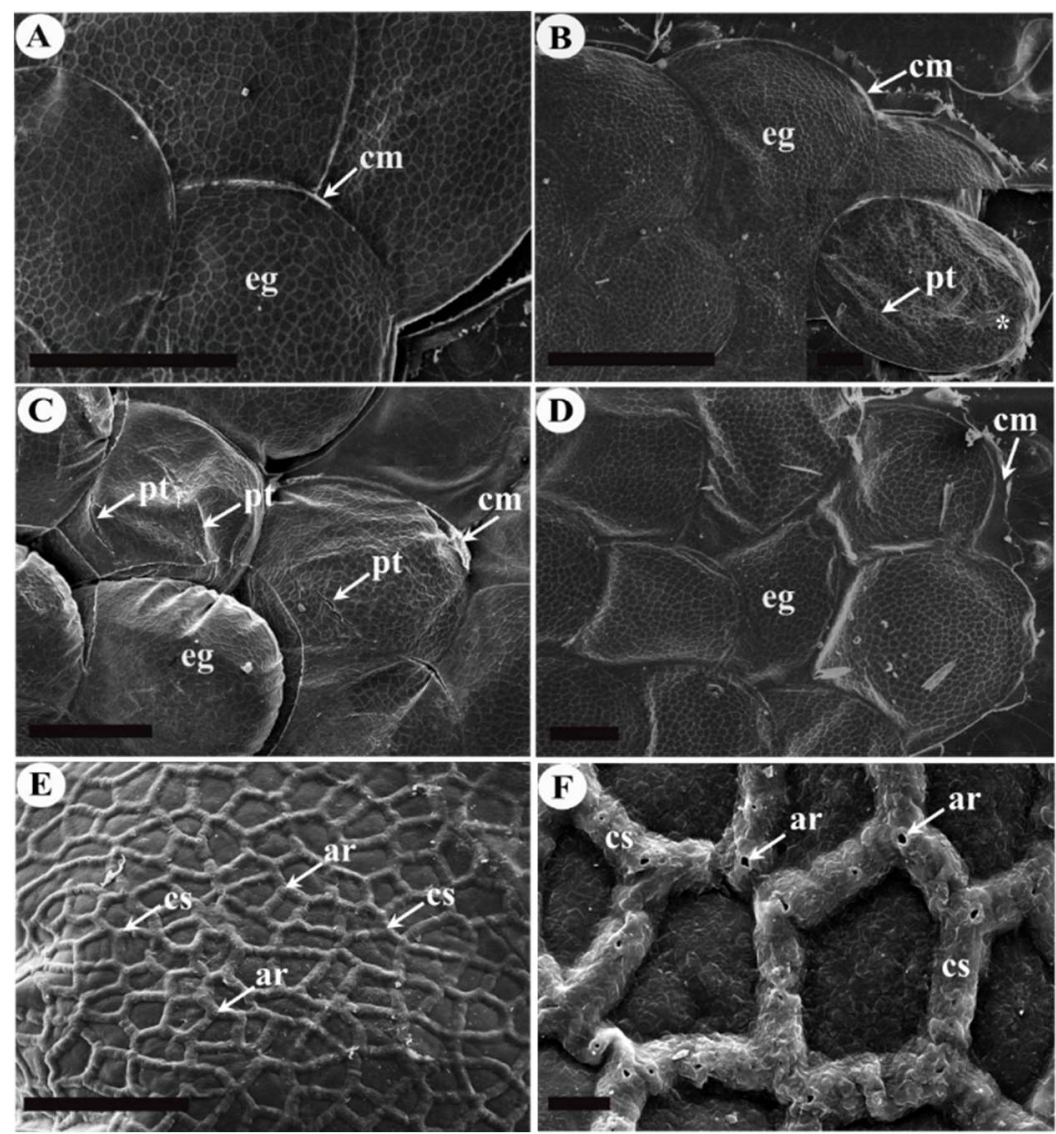

Figure 3: Scanning electron microscope images of control $D$. saccharalis eggs and eggs treated with $1 \%$ garlic essential oil. Control (A and E); After 24, 48, and 72-h of treatment (B, C, D, and F, respectively). (A) Eggs (e); Cement material (cm). (B) Eggs; Cement material; Protrusions (pt); bumps (*). (C) Eggs; Cement material; Protrusions. D) Eggs; Cement material. E) Chorus sculptures (cs); Aeropiles (ar). F) Chorus sculptures; Aeropiles. Scale bar. A-D = 500 $\mu \mathrm{m}$. E-F and insertion $=100 \mu \mathrm{m})$.

\section{DISCUSSION}

Few studies have evaluated the insecticidal effect of garlic oil extracts on insect eggs. The efficiency of bioinsecticides containing allicin on controlling other stages of insect development was previously described by Jarriel (2001), Douiri et al. (2013), Chaubey (2014), Nwachukwu et al. (2014), and Chaubey (2016).

Tavares et al. (2011) reported rates of unhatched eggs similar to those herein found; moreover, these authors reported that eggs treated with different concentrations of piperine had reduced rates of unhatched eggs as the concentrations decreased, and that the age of the $D$. saccharalis eggs increased, varying between $93 \%$ and $100 \%$, at concentrations $1 \%$ and $2 \%$ respectively. Karci et al. (2007) reported a $99.29 \%$ rate of unhatched eggs in 72-h. These results are similar to those of the present study, as we found that garlic oil extract caused a $91.7 \%$ rate of unhatched eggs in 24 h old eggs after 24 -h of exposure to a $0.5 \%$ concentration.

Gupta et al. (1993) suggested the toxic potential of allicin by using the immersion method, in which eggs of Meloidogyne incognita submerged at 25 ppm showed a $100 \%$ rate of unhatched eggs. This toxicity caused by garlic oil extract may be a result of the synergistic effect of its components, i.e., trisulfate and disulfate (HUANG et al., 2011). According to Prowse et al. (2006), the ovicidal effects may be a result of the direct contact of eggs with the garlic solution or of the exposure to the volatile form of allicin, as was described for Sitophilus zeamais (NWACHUKWU et al., 2014). Previous data support the results obtained in 
the present study, in which we observed reductions in the rate of embryo development of $D$. saccharalis eggs under different concentrations of garlic oil extract.

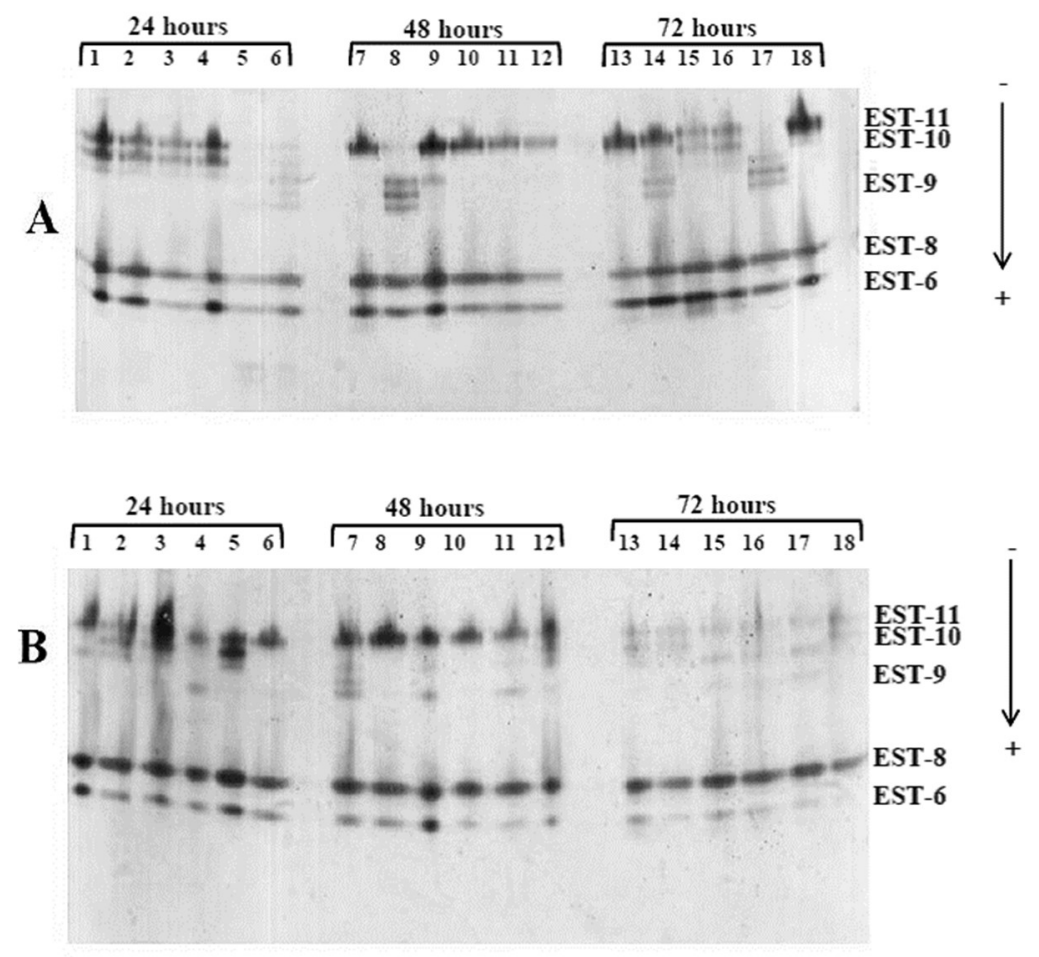

Figure 4: Esterase profile in $D$. saccharalis eggs. (A) control eggs; (B) eggs treated with 1\% garlic essential oil. 24-h-old (1-6), 48-h-old (7-12), and 72-h-old eggs (13-18).

Alterations in the external morphology of treated $D$. saccharalis eggs were observed in the total assembly and confirmed in the SEM analysis; these alterations and the partial rupture of the exochorion were also described for Aedes aegypti eggs exposed for two days to garlic oil extract (JARRIEL, 2001). The large number of aeropiles in the exochorion could explain this effect as a greater exposure to garlic oil extract may result in the obstruction of the aeropiles, thus preventing oxygenation. This alteration can also favor the bioinsecticide entering the egg and interfering in embryonic development (GAUTAM et al., 2014).

Mead et al. (2016) showed that after immersion in mahlab seed oil, eggs of Spodoptera frugiperda had ruptures on the exochorion surface and an increased number of folds on the surface. These results are similar to those of the present study, in which the reduced volume and increased chorionic protrusions of the eggs probably blocked the entrance of oxygen through the aeropiles.

D. saccharalis eggs are enveloped by a thin, transparent, and malleable membrane called chorion, through which morphological variations of the embryo such as the texture and colors can be observed during different levels of embryonic development. The chorion is composed of follicular cells of the ovary arranged in two layers: the exochorion and the endochorion (CÔNSOLI et al., 1999). The exochorion presents numerous aeropiles distributed on crests interconnected by bridges (BAKER et al., 2012; MEAD et al., 2016). The structure of the chorion delimits the homogeneously distributed yolk, which occupies most of the interior of the egg. Before embryo development, the majority of the cytoplasmic content is granular, formed by proteins, lipids, and glycogen (DOSSI et al., 2006). Glycogen (i.e., yolk) is essential for embryo nutrition until eclosion. The findings of Martínez-Morales et al. (2014) for Neochetina eichhorniae are similar to those herein 
shown for $D$. saccharalis. Initially, the dense material disaggregates from the periphery of the egg and forms the periplasm. This central content is then modified into specific characteristics, which differentiate each embryonic segment during the complete formation of the larva with brown appearance.

The melanization herein observed in the treated eggs is similar to that described by Vieira et al. (2013) for alterations and melanization in D. saccharalis eggs treated with neem oil, and Daquila et al. (2021) in eggs treated with Bacillus thuringiensis Aizawai-GC91. This melanization may be related to the immune system of D. saccharalis and its defense against external factors. The melanization process is controlled by proteases (Kanost et al., 2012; Jacobs et al., 2014) that trigger a cascade of serine proteases, which subsequently culminate in the activation of prophenoloxidase, a melanogenesis-controlling enzyme, and phenoloxidase, which oxidizes tyrosine to dihydroxyphenylalanine, resulting in the production of dihydroxyphenylalanine and dopamine, the precursors of melanin (Dubovskiy et al., 2008; Nakhleh et al., 2016). The presence of these enzymes in lepidopteran eggs was confirmed by Maki et al. (2001) and Kanost et al. (2012).

Esterases have essential functions related to behavior, reproduction (Roe et al. 1993), hormonal metabolism (YOO et al., 1996), digestive processes (KAPIN et al., 1980), lipid metabolism (ZHU et al., 1990) and resistance to insecticides (HEALY et al., 1991; VERMUNT et al., 1998; HAUBRUGE et al., 2002; BARATA et al., 2004). The expression of esterases has previously been studied during the development of $D$. saccharalis. Ruvolo-Takasusuki et al. (2002), described the electrophoretic profiles of eight esterases in adult sugarcane borers. Martins-Parra et al. (2016), identified seven esterases in larvae and pupae (EST-1, 2, 3, 4, 7, 8, and 9) and five esterases in adults (EST-3, 4, 7, 8, and 9) of D. saccharalis using naphthyl substrates. Mosconi (2012) identified 11 esterases (EST-1 to EST-11) that were expressed during the larval period in this species.

In the present study, five esterase regions were identified using PAGE: EST-6, 8, 9, 10, and 11, which are equivalent to esterases expressed in larvae as described by Mosconi (2012). These results indicate that esterases had different expression patterns in eggs of different ages as well as among batches of eggs of the same age; this possibly indicates the existence of regulatory mechanisms that increase or inhibit esterase expression according to the metabolic functions they perform during each embryonic period. Since these esterases initiate their expression in the embryonic period and continue to be expressed in all larval instars of this species (MARTINS-PARRA et al., 2016), including in pupae (RUVOLO-TAKASUSUKI et al., 2002), it is possible that these isoenzymes act on metabolic processes essential to insect development and survival, such as the metabolic detoxification of xenobiotics (PRICE, 1984).

To evaluate the participation of these isoenzymes in the detoxification process, eggs of different ages were exposed to the garlic oil extract. The 24 and 48 -h-old eggs showed high mortality rates and no change in esterase expression; therefore, it is possible that the bioinsecticide may have rapidly penetrated the eggs, crossing the physical barriers (chorion and extraembryonic membranes) (BLUM et al., 2008), as described by Beament (1949), and interfered in embryo formation.

Because of regulatory mechanisms, not all synthesized and stored enzymes act readily to contain and metabolize the garlic essential oil components (MONTELLA et al., 2012). The bioinsecticide could have acted in other physiological systems, interrupting embryonic development and causing the death of the embryos. 
Conversely, 72-h-old eggs showed low mortality rates, probably because of their greater resistance and the longer time of exposure to the diversity of environmental interactions. As larval development occurs predominantly in this period, the containment and metabolization of the garlic essential oil components possibly occurred with less intensity. In this case, EST-6, 9, 10, and 11 esterases, which were partially inhibited in the treated eggs, possibly participated in this metabolic detoxification process, as noted by (RILEY et al., 1999).

Each insect species seems to have unique genetic supplements, and the esterase family has shown rapid evolution (MONTELLA et al., 2012). Although the inhibition of esterases may suggest a low enzymatic activity, the reduction in the intensity of the bands in the gels may be correlated with the enzymatic degradation caused by the effect of allicin on eggs (DOUGOUD et al., 2019).

Changes in the expression of proteases may interfere with embryonic development. Proteases control the transduction of signals that regulate embryonic development (MORISATO et al., 1995; LEMOSY et al., 1999; MOUSSIAN et al., 2005), thus changes in these enzymes affect organogenesis and cause embryonic degeneration or malformation (KANOST et al., 2012). At all concentrations herein tested, $D$. saccharalis eggs showed absence or incomplete formation of the embryo, commonly with a reduction of the abdominal region. These results are in agreement with those of $S$. frugiperda eggs treated with azadirachtin for 24 and 72-h at different concentrations (CORREIA et al., 2013), in which the embryo was not formed or its incomplete formation was observed, besides a ruptured exochorion, absence of sculptures, and dehydrated eggs. Eggs of $D$. saccharalis treated with garlic oil extract presented these same alterations even at a relatively lower concentration than that of azadirachtin.

\section{CONCLUSIONS}

We thus conclude that garlic essential oil has a bioinsecticidal effect on $D$. saccharalis eggs, being toxic at all tested concentrations and periods of embryonic development. This effect may result from the inhibition of esterase and allicin acting on the insect's immune system and thus reducing the species' resistance to garlic essential oil. Therefore, we propose garlic essential oil as a potential tool for sustainable pest management.

ACKNOWLEDGEMENTS: We thank the Complex of Research Support Centers (COMCAP) and Coordination of Improvement of Higher Education Personnel (CAPES).

\section{REFERENCES}

ARAÚJO, J. R.. Guia prático para a criação da broca da canade-açúcar e de seus parasitóides em laboratório. Piracicaba: IAA/Planalsucar, 1987.

ATTIA, S.; GRISSA, K. L.; MAILLEUX, A. C.; LOGNAY, G.; HEUSKIN, S.; MAYOUFI, S.; HANCE, T.. Effective concentrations of garlic distillate (Allium sativum) for the control of Tetranychus urticae (Tetranychidae). Journal of Applied Entomology, v.136, n.4, p.302-312, 2011. DOI: http://doi.org/10.1111/j.1439-0418.2011.01640.x

BALLESTER, V.; GRANERO, F.; TABASHNIK, B. E.; MALVAR, T.; FERRÉ, J.. Integrative model for binding of Bacillus thuringiensis toxins in susceptible and resistant larvae of the Diamondback Moth (Plutella xylostella). Applied and Environmental Microbiology, v.65, n.4, p.1413-1419, 1999. DOI: http://doi.org/10.1128/AEM.65.4.1413-1419.1999 
BAKER, G. T.; HIGHT, S. D.; BROWN, R. L.. External morphology of the egg of the native (Melitara prodenialis) and exotic (Cactoblastis cactorum) cactus moths (Lepidoptera: Pyralidae). Proceedings of the Entomological Society of Washington, v.114, n.4, p.433-438, 2012. DOI: http://doi.org/10.4289/0013-8797.114.4.433

BARATA, C.; SOLAYAN, A.; PORTE, C.. Role of B-esterases in assessing toxicity of organophosphorus (chlorpyrifos, malathion) and carbamate (carbofuran) pesticides to Daphnia magna. Aquatic Toxicology, v.66, n.2, p.125-139, 2004. DOI: http://doi.org/10.1016/j.aquatox.2003.07.004

BEAMENT, J. W. L.. The penetration of insect egg-shells: II The properties and permeability of sub-chorial membranes during development of Rhodnius prolixus, Stål. Bulletin of Entomological Research, v.39, p.467-488, 1949. DOI: http://doi.org/10.1017/S0007485300022574

BELL, H. A.; CUTHBERTSON, A. G.; AUDSLEY, N.. The potential use of allicin as a biopesticide for the control of the house fly, Musca domestica L. International Journal of Pest Management, v.62, n.2, p.111-118, 2015. DOI: http://doi.org/10.1080/09670874.2015.1120363

BERGAMO, R. H. S.; DAQUILA, B. V.; CONTE, H.. Sustentabilidade agrícola com fungos entomopatogênicos. In: NETO, B. R. S.. Principais grupos e aplicações biotecnológicas dos fungos. Ponta Grossa: Atena, 2019. p.41-52. http://doi.org/10.22533/at.ed.3071918105

BLUM, M. S.; HILKER, M.. Chemical protection of insect eggs. In: HILKER, M.; MEINERS, T.. Chemoecology of insect eggs and egg deposition. New Jersey: Willey, 2008. p.61-90. DOI: http://doi.org/10.1002/9780470760253.ch3

CARVALHO, G. A. S.; MARTINS, D. J.; BRITO, I. M. C. ASSIS JÚNIOR, S. L.; SOARES, M. A.; LAIA, M. L.; VALICENTE, F. H.. Can Bacillus thuringiensis affect the biological variables of natural enemies of Lepidoptera? Arquivos do Instituto Biológico, v.85, p.1-6, 2018. DOI:

http://doi.org/10.1590/1808-1657000052018

CHAUBEY, M. K.. Biological activities of Allium sativum essential oil against pulse beetle, Callosobruchus chinensis (Coleoptera: Bruchidae). Herba Polonica, v.60, n.2, p.41-55, 2014. DOI: http://doi.org/10.2478/hepo-2014-0009

CHAUBEY, M. K.. Fumigant and contact toxicity of Allium sativum (Alliaceae) essential oil against Sitophilus oryzae L. (Coleoptera: Dryophthoridae). Entomology and Applied Science Letters, v.3, n.2, p.43-48, 2016

CHEN, P. S.. The functional morphology and biochemistry of insect male accessory glands and their secretion. Annual Review of Entomology, v.29, p.233-255, 1984. DOI: http://doi.org/10.1146/annurev.en.29.010184.001313

CLOYD, R. A.; GALLE, C. L.; KEITH S. R.; KALSCHEUR, N. A.; KEMP, K. E.. Effect of commercially available plant-derived essential oil products on arthropod pests. Journal of Economic Entomology, v.102, n.4, p.1567-1579, 2009. DOI: http://doi.org/10.1603/029.102.0422

CÔNSOLI, F. L.; KITAJIMA, E. W.; PARRA, J. R. P.. Ultrastructure of the natural and factitious host eggs of Trichogramma galloi Zucchi and Trichogramma pretiosum
Riley (Hymenoptera: Trichogrammatidae). International Journal of Insect Morphology and Embryology, v.28, n.3, p.211-231, 1999. DOI: http://doi.org/10.1016/S00207322(99)00026-4

CORREIA, A. A.; WANDERLEY-TEIXEIRA, V.; TEIXEIRA, A. A. C.; OLIVEIRA, J. V.; GONÇALVES, G. G. A.; CAVALCANTI, M. S. G.; BRAYNER, F. A.; ALVES, L. C.. Microscopic analysis of Spodoptera frugiperda (Lepidoptera: Noctuidae) embryonic development before and after treatment with azadirachtin, lufenuron, and deltamethrin. Journal of Economic Entomology, v.106, n.2, p.747-755, 2013. DOI: http://doi.org/10.1603/ec12158

COSTA, J.; NOVILLO, C.. Regulatory Approvals of GM Plants (Insect Resistant) in European Agriculture: Perspectives from Industry. In: SMAGGHE, G.; DIAZ, I.. Arthropod-Plant Interactions. Dordrecht: Springer, 2012. p.199-215. DOI: http://doi.org//10.1007/978-94-007-3873-7 8

DAQUILA, B. V.; CONTE, H.. Biotecnologia ambiental e desenvolvimento agrícola sustantável. In: AGUILEIRA, J. G.; ZUFFO, A. M.. A preservação do meio ambiente e o desenvolvimento sustentável. Ponta Grosa: Atena, 2019a. p.92-105. DOI: http://doi.org//10.22533/at.ed.36519140810

DAQUILA, B. V.; DOSSI, F. C. A.; MOI, D. A.; MOREIRA, D. R.; CALEFFE, R. R. T.; PAMPHILE, J. A.; CONTE, H.. Bioactivity of Bacillus thuringiensis (Bacillales: Bacillaceae) on Diatraea saccharalis (Lepidoptera: Crambidae) eggs. Pest Management Science, v.77, n.4, p.2019-2028, 2021. DOI: http://doi.org/10.1002/ps.6230

DAQUILA, B. V.; SCUDELER, E. L.; DOSSI, F. C. A.; MOREIRA, D. R.; PAMPHILE, J. A.; CONTE, H.. Action of Bacillus thuringiensis (Bacillales: Bacillaceae) in the midgut of the sugarcane borer Diatraea saccharalis (Fabricius, 1794) (Lepidoptera: Crambidae). Ecotoxicology and Environmental Safety, v.184, p.109642, 2019b. DOI: http://doi.org/10.1016/j.ecoenv.2019.109642

DAVIS, B. J.. Disc electrophoresis II. Methods and application to human serum proteins. Annals of the New York Academy of Sciences, v.72, p.404-427, 1964. DOI: http://doi.org/10.1111/j.1749-6632.1964.tb14213.x

DOSSI, F. C. A.; CONTE, H.; ZACARO, A. A.. Histochemical characterization of the embryonic stages in Diatraed saccharalis (Lepidoptera: Crambidae). Annals of the Entomological Society of America, v.99, n.6, p.1206-1212, 2006. DOI: http://doi.org/10.1603/00138746(2006)99[1206:HCOTES]2.0.CO;2

DOUGOUD, J.; TOEPFER, S.; BATEMAN, M.; JENNER, W. H.. Efficacy of homemade botanical insecticides based on traditional knowledge. A review. Agronomy for Sustainable Development, v.39, n.4, p.37, 2019. DOI: http://doi:10.1007/s13593-019-0583-1

DOUIRI, L. F.; BOUGHDAD, A.; ASSOBHEI, O.; MOUMNI, M.. Chemical composition and biological activity of Allium sativum essential oils against Callosobruchus maculates. Journal of Environmental Science, Toxicology and Food Technology, v.3, n.1, p.30-36, 2013. DOI: http://doi.org/10.9790/2402-0313036

DUBOVSKIY, I. M.; KRUKOVA, N. A.; GLUPOV, V. V.. 
Phagocytic activity and encapsulation rate of Galleria mellonella larval haemocytes during bacterial infection by Bacillus thuringiensis. Journal of Invertebrate Pathology, v.98, p.360-362, 2008. DOI: http://doi.org/10.1016/j.jip.2008.03.011

FONTES, E. M. G.; PIRES, C. S. S.; SUJII, E. R.; PANIZZI, A. R.. The environmental effects of genetically modified crops resistant to insects. Neotropical Entomology, v.31, n.4, p.497-513, 2002. DOI: http://doi.org/10.1590/S1519566X2002000400001

GAUTAM, S. G.; OPIT, G. P.; MARGOSAN, D.; HOFFMANN, D.; TEBBETS, J. S.; WALSE, S.. Comparative egg morphology and chorionic ultrastructure of key stored-product insect pests. Annals of the Entomological Society of America, v.108, n.1, p.43-56, 2014. DOI: http://doi.org/10.1093/aesa/sau001

GUPTA, R.; SHARMAJ, N. K.. A study of the nematicidal activity of allicin - an active principle in garlic, Allium sativum L., against root-knot nematode, Meloidogyne incognita (Kofoid and White, 1919) Chitwood, 1949. International Journal of Pest Management, v.39, n.4, p.390-392, 1993. DOI: http://doi.org/10.1080/09670879309371828

HAUBRUGE, E.; AMICHOT, M.; CUANY, A.; BERGE, J-B.; ARNAUD, L.. Purification and characterization of a carboxylesterase involved in malathion-specific resistance from Tribolium castaneum (Coleoptera: Tenebrionidae). Insect Biochemistry and Molecular Biology, v.32, n.9, p.1181-1190, 2002. DOI: http://doi.org/10.1016/S09651748(02)00054-1

HEALY, M. J.; DUMANCIC, M. M.; OAKESHOTT, J. G.. Biochemical and physiological studies of soluble esterases from Drosophila melanogaster. Biochemical Genetics, v.29, n.7-8, p.365-388, 1991. DOI: http://doi.org/10.1007/BF00554144

HUANG, Y.; CHEN, S. X.; HO, S. H.. Bioactivities of methyl allyl disulfide and diallyl trisulfide from essential oil of garlic to two species of stored-product pests, Sitophilus zeamais (Coleoptera: Curculionidae) and Tribolium castaneum (Coleoptera: Tenebrionidae). Journal of Economic Entomology, v.93, n.2, p.537-543, 2000. DOI: http://doi.org/10.1603/0022-0493-93.2.537

IBRAHIM, S. S.. Essential oil nanoformulations as a novel method for insect pest control in horticulture. In: BAIMEY, $H$. K.; HAMAMOUCH, N.; KOLOMBIA, Y. A.. Horticultural Crops. IntechOpen, 2020. p.1-14. DOI:

http://doi.org/10.5772/intechopen.80747

ISMAN, M. B.; MACHIAL, C. M.. Pesticides based on plant essential oils: from traditional practice to commercialization. In: RAI, M.; CARPINELLA, M.. Naturally Occurring Bioactive Compounds. Elservier, 2006. p.29-44. DOI: http://doi.org/10.1016/S1572-557X(06)03002-9

ISMAN, M. B.; GRIENEISEN, M. L.. Botanical insecticide research: many publications, limited useful data. Trends in Plant Science, v.19, n.3, p.140-145, 2014. DOI: http://doi:10.1016/j.tplants.2013.11.005

JACOBS, C. G. C.; SPAINK, H. P.; VAN DER ZEE, M.. The extraembryonic serosa is a frontier epithelium providing the insect egg with a full-range innate immune response. elife,
2014. DOI: http://doi.org/10.7554/eLife.04111

JARRIEL, M. S.. Toxic effect of garlic extracts on the eggs of Aedes aegypti (Diptera: Culicidae): a scanning electron microscopic study. Journal of Medical Entomology, v.38, n.3, p.446-450, 2001. DOI: http://doi.org/10.1603/00222585-38.3.446

KANOST, M. R.; CLEM, R. J.. Insect proteases. In: GILBERT, L. I.. Insect molecular biology and biochemistry. San Diego: Academic Press,2012, p.346-364. DOI: http://doi.org/10.1016/B978-0-12-384747-8.10010-8

KAPIN, M. A.; AHAMAD, S.. Esterases in larval tissue of gypsy moth Lymantria dispar L.: optimum assay conditions, quantification and characterization. Insect Biochemistry, v.10, p.331-337, 1980. DOI: http://doi.org/10.1016/00201790(80)90028-1

KARCI, A.; ISIKBER, A. A.. Ovicidal activity of various essential oils against confused flour beetle, Tribolium confusum Jacquelin duVal (Coleoptera: Tenebrionidae). Integrated Protection of Stored Products IOBC/wprs Bulletin, v.30, n.2, p.251-258, 2007.

KIM, H. S.; NOH, S.; PARK, Y.. Enhancement of Bacillus thuringiensis Cry1Ac and Cry1Ca toxicity Against Spodoptera exigua (Hubner) by suppression of a chitin synthase $B$ gene in midgut. Journal of Asia-Pacific Entomology, v.20, n.1, p.199-205, 2017. DOI: http://doi.org/10.1016/i.aspen.2016.12.015

LAEMMLI, U. K.. Cleavage of structural proteins during the assembly of the headof bacteriophage T4. Nature, v.227, p.680-685, 1970 .

LAUFER, H.. Forms of enzymes in insect development. Annals of the New York Academy Sciences, v.94, n.3, p.825835, 1961. DOI: http://doi.org/10.1111/j.17496632.1961.tb35576.x

LEMOSY, E. K.; HONG, C. C.; HASHIMOTO, C.. Signal transduction by a protease cascade. Trends in Cell Biology, v.9, p.102-107, 1999. DOI: http://doi.org/10.1016/s09628924(98)01494-9

LIAO, J.; XUE, Y.; XIAO, G.; XIE, M.; HUANG, S.; YOU, S.; WYCKHUYS, K. A. G.; YOU, M.. Inheritance and fitness costs of resistance to Bacillus thuringiensis toxin Cry2Ad in laboratory strains of the diamondback moth, Plutella xylostella (L.). Scientific Reports, v.9, n.1, p.1-8, 2019. DOI: http://doi.org/10.1038/s41598-019-42559-2

LOURENÇO, A. M.; HADDI, K.; RIBEIRO, B. M.; CORRÊIA, R. F. T.; TOMÉ, H. V. V.; SANTOS-AMAYA, O.; PEREIRA, E. J. G.; GUEDES, R. N. C.; SANTOS, G. R.; OLIVEIRA, E. E.; AGUIAR, R. W. S.. Essential oil of Siparuna guianensis as an alternative tool for improved lepidopteran control and resistance management practices. Scientific Reports, v.8, n.1, p.1-13, 2018. DOI: http://doi.org/10.1038/s41598-018-25721-0

MAGIEROWICZ, K.; GÓRSKA-DRABIK, E.; GOLAN, K.. Effects of plant extracts and essential oils on the behavior of Acrobasis advenella (Zinck.) caterpillars and females. Journal of Plant Diseases and Protection, v.127, p.63-71, 2020. DOI: http://doi.org/10.1007/s41348-019-00275-z 
MAKI, N.; YAMASHITA, O.. The 30k protease a responsible for 30-kDa yolk protein degradation of the silkworm, Bombyx mori: cDNA structure, developmental change and regulation by feeding. Insect Biochemistry and Molecular Biology, v.31, n.4-5, p.407-413, 2001. DOI: http://doi.org/10.1016/s0965-1748(00)00135-1

MARTÍNEZ-MORALES, O.; ESTRADA-VENEGAS, E. G.; EQUIHUA-MARTÍNEZ, A.; VALDEZ-CARRASCO, J.. Morfología de Neochetina Eichhorniae (Warner) (Coleoptera: Curculionidae). Acta Zoológica Mexicana, v.30, n.2, p.247267, 2014. DOI: http://doi.org/10.21829/azm.2014.302101

MARTINS-PARRA, F.; FIGUEIREDO, V. L. C.; ISSA, M. R. C.; ALMEIDA, R.. Esterase pattern during the ontogenetic development of Diatraea saccharalis Fabr. (Lepidoptera: Pyralidae). Revista de Saúde e Biologia, v.11, n.3, p.17-28, 2016.

MEAD, H. M.; EL-SHAFIEY, S. N.; SABRY, H. M.. Chemical constituents and ovicidal effects of mahlab, Prunus mahaleb L. kernels oil on cotton leafworm, Spodoptera littoralis (Boisd.) eggs. Journal of Plant Protection Research, v.56, n.3, p.279-290, 2016. DOI: http://doi.org/10.1515/jppr2016-0044

MIRESMAILLI, S.; ISMAN, M. B.. Efficacy and persistence of rosemary oil as an acaricide against two spotted Spider Mite (Acari: Tetranychidae) on greenhouse tomato. Journal of Economic Entomology, v.99, n.6, p.2015-2023, 2006. DOI: http://doi.org/10.1603/0022-0493-99.6.2015

MONTELLA, I. R.; SCHAMA, R.; VALLE, D.. The classification of esterases: an important gene family involved in insecticide resistance - A review. Memórias do Instituto Oswaldo Cruz, v.107, n.4, p.437-449. DOI: http://doi:10.1590/s007402762012000400001

MORIATO, D.; ANDERSON, K.. Signaling pathways that establish the dorsal: ventral pattern of the Drosophila embryo. Annual Reviews of Genetics, v.29, p.371-399, 1995 DOI: http://doi.org/10.1146/annurev.ge.29.120195.002103

MOSCONI, J. M.. Alterações moleculares e morfológicas em Diatraea saccharalis (Fabricius, 1794) (Lepidoptera: Crambidae) tratadas com inseticida regulador de crescimento Gallaxy EC 100. Dissertação (Mestrado em Genética e Melhoramento) - Universidade Estadual de Maringá, Maringá, 2012.

MOUSSIAN, B.; ROTH, S.. Dorsoventral axis formation in the Drosophila embryo-Shaping and transducing a morphogen gradient. Currelent Biology, v.15, n.21, p.R887-R899, 2005. DOI: http://doi.org/10.1016/j.cub.2005.10.026

NAKHLEH, J.; EL-MOUSSAWI, L.; OSTA, M. A.. The melanization response in insect immunity. In: LIGOXYGAKIS, Petros (ed.). Advances in insect Physiology. ScienciDirect, v.52, p.83-109, 2016. Dol:

http://doi.org/10.1016/bs.aiip.2016.11.002

NWACHUKWU, I. D.; ASAWALAM, E. F.. Evaluation of freshly prepared juice from garlic (Allium sativum L.) as a biopesticide against the maize weevil, Sitophilus zeamais (Motsch.) (Coleoptera: Curculionidae). Journal of Plant Protection Research, v.54, n.2, p.132-138, 2014. DOI: http://doi.org/10.2478/jppr-2014-0021
OSMAR, K.; AL-EMAM, A.; MOUSTAFA, M.. Secondary plant products against Culex pipiens (Linn.), with reference to some changes detected by scanning electron microscope. Egyptian Journal of Biological Pest Control, v.30, n.32, p.1-7, 2020. DOI: http://doi.org/10.1186/s41938-020-00228-x

PRICE, N. R.. Carboxyesterase degradation of malathion in vitro by susceptible and resistant strains of Tribolium castaneum (Herbst) (Coleoptera, Tenebrionidae). Comparative Biochemistry and Physiology, v.77, n.1, p.9598, 1984. DOI: http://doi.org/10.1016/0742-8413(84)901361

PROWSE, G. M.; GALLOWAY, T. S.; FOGGO, A.. Insecticidal activity of garlic juice in two Dipteran pests. Agricultural and Forest Entomology, v.8, n.1, p.1-6, 2006. DOI: http://doi.org/10.1111/i.1461-9555.2006.00273.x

RAIKHEL, A. S.; DHADIALLA, T. S.. Accumulation of yolk proteins in insect oocytes. Annual Review of Entomology, v.37, n.1, p.217-251, 1992. DOI:

http://doi.org/10.1146/annurev.en.37.010192.001245

RIAZ, S.; NAASIR, I. A.; BHATTI, M. U.; ADEYINKA, O. S.; TOUFIQ, N.; YOUSAF, I.; TABASSUM, B.. Resistance to Chilo infuscatellus (Lepidoptera: Pyraloidea) in transgenic lines of sugarcane expressing Bacillus thuringiensis derived Vip3A protein. Molecular Biology Reports, v.47, p.2649-2658, 2020. DOI: http://doi.org/10.1007/s11033-020-05355-0

RILEY, D. G.; TAN, W-J.; WOLFENBARGER, D.. Esterase isozymes associated with bifenthrin resistance in the silverleaf whitefly (Homoptera: Aleyrodidae). Journal of Entomological Science, v.34, n.3, p.295-304, 1999.

ROE, R. M.; JESUDAN, P.; VENKATESHI, K.; KALLAPUR, V. L.; ANSPAUGH, D. D.; MAJUMDER, C.. Developmental Role of Juvenile Hormone Metabolism in Lepidoptera. American Zoologist, v.33, p.375-383, 1993. DOI: http://doi.org/10.1093/icb/33.3.375

RUVOLO-TAKASUSUKI, M. C. C.; MACHADO, F. P. S. M.; CONTE, H.. Esterase-3 polymorphism in the sugarcane borer Diatraea saccharalis (Lepidoptera, Pyralidae). Genetics and Molecular Biology, v.25, n.1, p.61-64, 2002. DOI: http://doi.org/10.1590/S1415-47572002000100012

SANTOS, F. C. C.; VOGEL, F. S. F.; MONTEIRO, S. G.. Extrato aquoso de alho (Allium sativum) sobre nematóides gastrintestinais de ovinos. Revista Brasileira de Agroecologia, v.7, n.1, p.139-144, 2012.

SHARE, M. R.; VENKATESH, K.; JESUDASON, P.; ROE, R. M.. Juvenile hormone metabolism during embryogenesis in the tobacco hornworm, Manduca sexta (L.). Archives of Insect Biochemistry and Physiology, v.8, n.3, p.173-186, 1988. DOI: http://doi.org/10.1002/arch.940080304

SCHNEIDER, L. C.; SILVA, C. V.; CONTE, H.. Toxic effect of commercial formulations of neem oil, Azadirachta indica A. Juss., in pupae and adults of the sugarcane borer, Diatraea saccharalis F. (Lepidoptera: Crambidae). Arquivos do Instituto Biológico, v.84, p.1-8, 2017. DOI: http://doi.org/10.1590/1808-1657000432014

SCUDELER, E. L.; GARCIA, A. S. G.; PADOVANI, C. R.; SANTOS, 
D. C.. Pest and natural enemy: how the fat bodies of both the southern armyworm Spodoptera eridania and the predator Ceraeochrysa claveri react to azadirachtin exposure. Protoplasma, v.256, p.839-856, 2019. DOI: http://doi.org/10.1007/s00709-019-01347-5

SHU-SHENG, L.; GUANG-MEI, Z.. Effects of Bacillus thuringiensis on eggs of three lepidopterous pests of crucifer vegetable crops. In: SILVAPRAGASAN, A.; LOKE, W. H.; HUSSAN A. K.; LIM G. S.. The management of diamondback moth and other cruciferous pests. Malaysian Agricultural Research and Development Institute, Kuala Lumpur, Malaysia, 1997. p.109-112.

SILVA, C. V.; SCHNEIDER, L. C. L.; CONTE, H.. Toxicity and residual activity of a commercial formulation of oil from neem, Azadirachta indica A. Juss. (Meliaceae), in the embryonic development of Diatraea saccharalis F. (Lepidoptera: Crambidae). Journal of Agricultural Science and Food Research, v.4, n.131, p.1-5, 2013. DOI: http://doi.org/10.4172/2155-6202.1000131

SILVA, W.; FREIRE, M. G. M.; PARRA, J. R. P.; MARANGONI, S.; MACEDO, M. L. R.. Evaluation of the Adenanthera pavonina seed proteinase inhibitor (ApTI) as a bioinsecticidal tool with potential for the control of Diatraea saccharalis. Process Biochemistry, v.47, n.2, p.257-263, 2012. DOI: http://doi.org/10.1016/j.procbio.2011.11.002

TAVARES, W. S.; CRUZ, I.; PETACCI, F.; FREITAS, S. S.; SERRÃO, J. E.; ZANUNCIO, J. C.. Insecticide activity of piperine: toxicity to eggs of Spodoptera frugiperda (Lepidoptera: Noctuidae) and Diatraea saccharalis (Lepidoptera: Pyralidae) and phytotoxicity on several vegetables. Journal of Medicinal Plant Research, v.5, n.21, p.5301-5306, 2011.

TERRIERE, L. C.. Induction of detoxication enzymes in insects. Annual Review of Entomology, v.29, n.1, p.71-88, 1984. DOI: http://doi:10.1146/annurev.en.29.010184.000443

TSAI, C-W.; CHEN, H-W.; SHEEN, L-Y.; LII, C-K.. Garlic: Health benefits and actions. BioMedicine, v.2, n.1, p.17-29, 2012. DOI: http://doi.org/10.1016/j.biomed.2011.12.002

VERMUNT, A. M. W.; KOOPMANSCHAP, A. B.; VLAK, J. M.;
KORT, C. A. D.. Evidence for two juvenile hormone esteraserelated genes in the Colorado potato beetle. Insect Molecular Biology, v.7, n.4, p.327-336, 1998. DOI: http://doi.org/10.1046/j.1365-2583.1998.740327.x

VILLEGAS-AGUDELO, D.; SOTO-GIRALDO, A.; MEJÍAGUTÍEREZ, L. F.. Other alternatives for the control of Diatraea saccharalis Fabricius (Lepidoptera: Crambidae) in sugar cane cultivation. Boletín Científico, Centro de Museos, Museus de História Natural, v.23, n.2, p.162-170, 2019. DOI: http://doi.org/10.17151/bccm.2019.23.2.8

VIEIRA, D. L.; SOUZA, G. M. M.; OLIVEIRA, R.; BARBOSA, V. O.; BATISTA, J. L.; PEREIRA, W. E.. Aplicação de óleos comerciais no controle ovicida de Aleurocanthus woglumi asbhy. Bioscience Journal, v.29, n.5, p.1126-1129, 2013.

XU, X. X.; ZHAG, Y. Q.; FREED, S., YU, J.; GAO, Y. F.; WANG, S.; OUYANG, L. N.; JU, W. Y.; JIN, F. L.. An anionic defensin from Plutella xylostella with potential activity against Bacillus thuringiensis. Bulletin of Entomological Research, v.106, n.6, p.790-800, 2016. DOI: http://doi.org/10.1017/S0007485316000596

YANG, Y.; XU, H.; LU., Y.; WANG, C.; LU, Z.. Midgut transcriptomal responses of the rice leaffolder, Cnaphalocrocis medinalis (Guenée) to Cry1C toxin. PloS One, v.13, n.1, p.e0191686, 2018. DOI: http://doi.org/10.1371/journal.pone.0191686

YANG, F-L.; ZHU, F.; LEI, C-L.. Insecticidal activities of garlic substances against adults of grain moth, Sitotroga cerealella (Lepidoptera: Gelechiidae). Insect Science, v.19, n.2, p.2052012, 2011. DOI: http://doi.org/10.1111/j17447917.2011.01446.x

YOO, C. M.; BAK, B. C.; LEE, C. H.. Substrate and inhibitor specificities of esterase in Lucilia illustris, Meigen. Koran Journal of Zoology, v.39, n.2, p.190-197, 1996.

ZHU, K. Y.; BRINDLEY, W. A.. Properties of esterases from Lygus hesperus Knight (Hemiptera: Miridae) and the roles of the esterases in insecticide resistance. Journal of Economic Entomology, v.83, n.3, p.725-727, 1990. Dol: http://doi.org/10.1093/jee/83.3.725

A CBPC - Companhia Brasileira de Produção Científica (CNPJ: 11.221.422/0001-03) detém os direitos materiais desta publicação. Os direitos referem-se à publicação do trabalho em qualquer parte do mundo, incluindo os direitos às renovaç̃̃es, expansões e disseminacões da contribuicão, bem como outros direitos subsidiários. Todos os trabalhos publicados eletronicamente poderão posteriormente ser publicados em coletâneas impressas sob coordenação da Sustenere Publishing, da Companhia Brasileira de Produção Científica e seus parceiros autorizados. Os (as) autores (as) preservam os direitos autorais, mas não têm permissão par coordenção da Sustenere Publishing, da Companhia Brasileira de Produçăo cientíca e seus parce 